\title{
Literasi Digital, Sebuah Tantangan Baru Dalam Literasi Media
}

\author{
Ajani Restianty \\ Corporate Communication/Postgraduate Programme, London School of Public Relations \\ Jakarta, \\ ajani@upi.edu
}

\begin{abstract}
ABSTRAK
Seiring dengan perkembangan komunikasi dan teknologi informasi, diiringi dengan pesatnya teknologi digital, kesadaran dan kemampuan bermedia. Literasi media dan literasi digital merupakan pendekatan yang memiliki fokus analisis kritis terhadap konten dari pesan media. Paparan berbagai macam informasi dari media membuat kebanyakan orang kebingungan mana informasi yang bermanfaat dan mana yang tidak. Maka dengan adanya fenomena tersebut, pengetahuan literasi media sangat dibutuhkan sebagai modal bagi khalayak untuk memiliki kemampuan dalam memilah dan mengevaluasi isi media dengan tajam dan teliti sehingga mampu memanfaatkan isi media sesuai dengan kebutuhannya. Setiap orang harus memiliki tanggung jawab atas penggunaan teknologi untuk berinteraksi atau berkomunikasi dalam kehidupannya sehari-hari. Menangani beraneka informasi, kemampuan dalam menafsirkan pesan dan berkomunikasi secara efektif dengan orang lain merupakan berbagai kemampuan dalam literasi digital. Adanya proses menciptakan, mengolaborasi, mengkomunikasikan berdasarkan etika, memahami kapan dan bagaimana menggunakan teknologi secara efektif merupakan kompetensi digital yang dibutuhkan saat ini.

Dalam penelitian ini, peneliti menggunakan metode penelitian deskriptif kualitatif karena penelitian ini mendalami fenomena perkembangan literasi digital sebagai salah satu tantangan baru dalam literasi media. Metode pengumpulan data yang dilakukan ialah observasi dan studi dokumentasi. Literasi media melibatkan pemahaman, cara menafsirkan, tingkat analisis kritis dan penyusunan kesimpulan dari teks untuk menjadi subjek penelitian pada berbagai bidang mulai dari komunikasi, sastra, budaya, ekonomi, sejarah, pengetahuan umum dan tentunya kajian media. Dalam literasi digital, pesan di media dikonstruksi sedemikian rupa sehingga mampu berfungsi maksimal dalam situasi komunikasi yang lebih kompleks sekalipun. Literasi digital memiliki skala yang lebih luas dan biasanya membahas isu penting. Pendidikan literasi digital dapat dimulai dari mengasah keterampilan dalam membaca konten, dengan rajin membaca konten, maka penggunaan literasi digital untuk pemahaman konten akan lebih kritis.

Komunikasi saat ini mengimplikasikan tidak hanya pada bagaimana sebuah teks dibuat, melainkan melibatkan proses pemilihan, pengaturan, filterisasi dan bagaimana cara merangkai kembali informasi yang sudah diterima. Fenomena teknologi digital semakin menguatkan bagian dasar dari literasi digital yaitu bagaimana mendapatkan informasi dan menghubungkannya dengan konteks yang akan dibuat. Sebagai warga negara yang bertanggung jawab, maka diperlukan pemahaman yang lebih luas tentang akses, analisis, evaluasi kritis dan pembuatan konten yang lebih mengarah pada perkembangan media baru.
\end{abstract}

Kata Kunci: Literasi media, literasi digital, internet, media sosial

\begin{abstract}
Along with the development of communication and information technology, accompanied by rapid digital technology, awareness and ability to media. Media literacy and digital literacy is an approach that focuses critical analysis of the content of media messages. Exposure to a variety of information from the media makes most people confused where
\end{abstract}


useful information and which are not. So with the phenomenon, the knowledge of media literacy is needed as a capital for the audience to have the ability to sort and evaluate the content of the media sharply and thoroughly so as to utilize the media content in accordance with their needs. Everyone should have responsibility for the use of technology to interact or communicate in their daily lives. Dealing with diverse information, the ability to interpret messages and communicate effectively with others is a variety of capabilities in digital literacy. The process of creating, collaborating, communicating based on ethics, understanding when and how to use technology effectively is the digital competence required today.

In this study, researchers used descriptive qualitative research method because this research deepens the phenomenon of digital literacy development as one of the new challenges in media literacy. Data collection methods are observation and documentation study. Media literacy involves understanding, how to interpret, the level of critical analysis and the conclusion of the text to be the subject of research in various fields ranging from communication, literature, culture, economics, history, general knowledge and of course media studies. In digital literacy, messages in the media are constructed in such a way as to be capable of functioning in a more complex communication situation. Digital literacy has a wider scale and usually addresses important issues. Digital literacy education can be started from sharpening skills in reading content, by diligently reading the content, then the use of digital literacy for content understanding will be more critical.

Current communication implies not only how a text is made, but rather involves the process of selecting, setting, filtering and how to re-assemble the information already received. The phenomenon of digital technology further strengthens the basic parts of digital literacy is how to get information and relate it to the context to be created. As responsible citizens, a broader understanding of access, analysis, critical evaluation and content creation is likely to lead to the development of new media.

Keywords: Media literacy, digital literacy, internet, social media

\section{PENDAHULUAN}

Internet merupakan hasil peradaban, yang seharusnya digunakan oleh manusia untuk membentuk aktivitas yang beradab pula. Tetapi pada kenyataannya, internet tidak hanya memberikan dampak positif, tetapi juga dampak negatif. Dampak positif timbul apabila internet digunakan untuk sarana pembelajaran, inovasi, memberikan inspirasi dan alat marketing. Sedangkan dampak negatif apabila internet digunakan sebagai alat propaganda negatif, intimidasi, sarana memecah belah SARA bahkan terorisme dan perdagangan narkoba.
Dampak ini terpaut pada cara dan tujuan menggunakannya. Di jaman digital sekarang ini, jumlah informasi yang diterima setiap orang pada gawai yang digunakannya menjadi semakin banyak dan cenderung tidak terkontrol. Kemudian yang menjadi penting ialah kemahiran seseorang dalam memilih dan memilah informasi. Hal ini menjadi sesuatu yang sifatnya mendesak, karena semakin berkembangnya tantangan teknologi informasi dan gaya komunikasi yang baru.

Media massa merupakan media yang dipakai secara massive untuk 
menyebarluaskan berbagai informasi baik itu berita, pendidikan maupun hiburan kepada khalayak. Berdasarkan fungsinya, media massa digunakan untuk memberikan informasi, mendidik, membentuk opini atau pendapat dan untuk menghibur. Media literasi berkembang dikarenakan pada kenyataannya fungsi media massa saat ini lebih dominan untuk menghibur daripada ketiga fungsi lainnya.

Paparan berbagai macam informasi dari media membuat kebanyakan orang kebingungan mana informasi yang bermanfaat dan mana yang tidak. Maka dengan adanya fenomena tersebut, pengetahuan literasi media sangat dibutuhkan sebagai modal bagi khalayak untuk memiliki kemampuan dalam memilah dan mengevaluasi isi media dengan tajam dan teliti sehingga mampu memanfaatkan isi media sesuai dengan kebutuhannya.

Generasi muda yang telah akrab dengan dunia digital atau lebih dikenal sebagai digital native atau generasi millenial, belajar, bermain dan bersosialisasi dengan menggunakan internet atau media sosial. Sekarang generasi digital native ini terpapar berbagai konten dari media sosial, dimana bagi mereka yang belum memiliki kemampuan dan kepekaan dalam menyaring konten tersebut, akan menjadi kesulitan dalam menerima informasi. Mereka hanya mampu untuk mengakses media digital tanpa mengimbanginya dengan kemampuan memperoleh informasi untuk pengembangan diri meraka. Masyarakat semakin mudah mendapatkan informasi yang sangat bermacam-macam baik jenis, kadar relevansi dan tingkat validasinya. Fenomena media sosial menjadi bagian yang tidak terpisahkan dalam kehidupan saat ini. Eksistensi media sosial menyampaikan gambaran seakan-akan dunia tanpa batasan.

\section{Literasi Digital}

Masyarakat kita, terutama generasi muda membutuhkan perhatian, bimbingan dan pendampingan dari orang tua, pendidik juga pemerintah, karena mereka sangat rentan dalam memperoleh konten-konten atau informasi negatif terutama dari media sosial, yang akan berpengaruh pada cara berperilaku mereka. Hal ini menjadikan literasi digital semakin dibutuhkan sebagai salah satu program utama untuk memberikan edukasi dan juga advokasi bagi para pengguna internet, khususnya pengguna media sosial.

Untuk berinteraksi di jaman sekarang ini dibutuhkan pemahaman literasi digital, yang sama pentingnya dengan pemahaman ilmu lainnya. Karena generasi millenial yang tumbuh dengan akses tidak terbatas terhadap teknologi memiliki gaya berpikir yang tidak sama dengan generasi 
sebelumnya. Setiap orang harus memiliki tanggung jawab atas penggunaan teknologi untuk berinteraksi atau berkomunikasi dalam kehidupannya sehari-hari. Konten di media yang berisi berita bohong, bertipu daya, mengandung ujaran kebencian bahkan radikalisme dapat mengganggu ekosistem digital yang ada dengan menciptakan pemahaman dari tiap-tiap individu pengguna.

Menangani beraneka informasi, kemampuan dalam menafsirkan pesan dan berkomunikasi secara efektif dengan orang lain merupakan berbagai kemampuan dalam literasi digital. Adanya proses menciptakan, mengolaborasi, mengkomunikasikan berdasarkan etika, memahami kapan dan bagaimana menggunakan teknologi secara efektif merupakan kompetensi digital yang dibutuhkan saat ini. Pendidikan literasi digital perlu diupayakan seluruh lapisan pemangku kepentingan mulai dari orang tua, guru/pendidik, lembaga pendidikan, dan pemerintah dalam memberikan panduan, arahan dan petunjuk agar tercipta tatanan masyarakat dengan pola pikir dan cara pandang yang kritis dan kreatif sehingga membangun kehidupan sosial dan masyarakat yang kondusif.

\section{Literatur Dan Metodologi}

Teori yang digunakan pada penelitian ini ialah New Media Theory. Teori new media mulai berkembang sejak tahun 1990- an ketika terjadinya difusi media digital yang bergerak cepat di bidang teknologi informasi dan telekomunikasi sehingga tinjauan tentang media serta komunikasi menjadi objek penelitian baru. Studi pada teori new media menyatakan bahwa kondisi komunikasi media tradisional telah bergeser dengan adanya inovasi teknologi sehingga terjadi transformasi substansial pada pertumbuhan komunikasi yang menggunakan media.

McLuhan dalam Littlejohn (2009) menyatakan bahwa kemunculan informasi instan berawal dari tersedianya internet. Revolusi bidang media elektronik terjadi akibat adanya perubahan media informasi yang biasanya didapatkan dari siaran menjadi dalam bentuk jaringan media elektronik. Penelitian media baru mulai bermunculan tentang globalisasi dan konvergensi media, internet menjadi alternatif media dalam menyajikan informasi tanpa adanya kendala teknis dari model siaran. McLuhan juga menambahkan pada era media baru berkembang juga studi internet dan cyberstudies yang menggeserkan perhatian khalayak pada media digital yang menandai perkembangan teknologi informasi dan komunikasi yang baru.

Dalam media baru, teknologi dikembangkan dalam bentuk kode digital yang dapat dikoneksikan dan dioperasionalkan dalam semua platform 
media. Kode digital menjadi sumber primer penyimpanan dan pendistribusian data bagi aktivitas telekomunikasi. Dengan digitalisasi, internet akan menjadi sumber informasi utama yang mampu menggabungkan semua media mulai dari koran, majalah, tabloid hingga radio, televisi, telepon dan komputer secara digital. Jenkins dalam Littlejohn (2009) menyatakan bahwa pengguna media lama lebih terisolasi, sedangkan pengguna media baru lebih terhubung secara sosial karena dapat berinteraksi dengan mengunggah konten mereka sendiri, juga memilih beragam informasi yang tersedia, sehingga interoperabilitas media baru menjadikan adanya partisipasi pengguna media yang lebih aktif.

Sebagai alat yang memisahkan jarak antara transportasi dan komunikasi, komputer mengenalkan adanya dunia maya kepada khalayak. Pengguna komputer dapat mengirim pesan dengan adanya perkembangan kecepatan komunikasi, pengguna dapat mengabaikan jarak dan waktu yang dibutuhkan untuk berkomunikasi, karena pesan dapat disampaikan dan diterima secara real time. Internet dan teknologi digital pendukungnya memiliki kelebihan berupa bandwith dan kapabilitas dalam meneruskan format yang lebih rumit dalam komponen ruang dan waktu yang lebih cepat.
Ketika berinteraksi dengan media komunikasi, keterikatan pada media juga turut dipengaruhi oleh efisiensi dan kontrol pengguna atas media. Turkle dalam Littlejohn (2009) mengeksplorasi mengenai bagaimana seseorang menggunakan komputernya seakan-akan memiliki pikiran dan jiwa, yang kemudian menjadi seperti menggantikan proses interaksi dengan manusia secara langsung. Dalam komunikasi digital, pengguna memiliki identitas online, sehingga pengguna dapat mengendalikan seberapa banyak ia akan mengungkapkan identitasnya, apakah banyak, sedikit atau tidak sama sekali ke hadapan publiknya di dunia maya, maka pengguna pada umumnya jadi merasa lebih nyaman untuk berekspresi di dunia maya.

Interaksi dengan menggunakan platform web 2.0 juga telah mengubah pola interaksi yang menjadkan pengguna dapat memproduksi kontennya sendiri dan mengalami kesempatan siaran dengan menggunakan platform seperti blog, youtube, facebook, instagram dan situs jejaring sosial online lainnya. Konten yang dibagikan pun beragam mulai dari teks, gambar, audio hingga video untuk menyampaikan informasi, ide atau gagasan kepada publik.

Konvergensi media pada teori new media memperlihatkan ruang lingkup dan jangkauan media yang lebih terbuka 
daripada sebelumnya yang menciptakan kepekaan sensorik. Hanya dengan mengklik mouse, menekan tombol like/subscribe menjadikan pengguna memiliki otoritas penuh atas media yang digunakannya. Teori media baru terus sejalan dengan perkembangan bidang komputerisasi, media dan telekomunikasi. Luasnya sumber informasi yang tersedia dan semakin banyaknya pengguna internet di dunia menjadikan kompleksitas media baru terus meningkat yang dipengaruhi oleh determinisme sosial dan juga teknologi.

\section{Literasi Media}

Kutipan dalam teks:

Menurut Potter (2004),

"Media Literacy is a set of perspectives that we actively use to expose ourselves to the media to interpret the meaning of the messages we encounter. We build our perspectives from knowledge structures. To build our knowledge structures, we need tools and raw material. These tools are our skills. The raw material is information from the media and from the real world. Active use means that we are aware of the messages and are consciously interacting with them. “

Potter menyatakan bahwa melek media adalah satu set perspektif yang aktif kita gunakan untuk membuka diri kepada media untuk menafsirkan makna pesan yang kita hadapi. Kita membangun perspektif kita dari struktur pengetahuan. Untuk membangun struktur pengetahuan, kita perlu alat dan bahan baku. Alat-alat adalah keterampilan kita sedangkan bahan baku adalah informasi dari media dan dari dunia nyata. Aktif menggunakan berarti kita memahami pesan dan berinteraksi secara sadar. Potter juga menambahkan bahwa literasi media adalah sebuah perspekif yang digunakan secara aktif ketika, individu mengakses media dengan tujuan untuk memaknai pesan yang disampaikan oleh media.

Wikipedia, the free encyclopedia, menyebutkan bahwa literasi media adalah keterampilan untuk memahami sifat komunikasi, khususnya dalam hubungannya dengan telekomunikasi dan media massa. Konsep ini diterapkan pada beragam gagasan yang berupaya untuk menjelaskan bagaimana media menyampaikan pesan-pesan mereka, dan mengapa demikian.

Literasi media atau dalam bahasa Indonesia lebih dikenal dengan melek media dianggap sebagai sebuah jawaban dari banyaknya persepsi publik mengenai pengaruh dan dampak yang muncul dari konten yang ada di media massa yang cenderung negatif, sehingga dibutuhkan kemampuan, pengetahuan, kesadaran dan keterampilan bagi para publik untuk mengevaluasi pesan secara kritis. Dalam 
evaluasi pesan terdapat proses seleksi pesan, interpretasi dan evaluasi dampak dari pesan-pesan yang diterima tersebut.

\section{Literasi digital}

Literasi digital menurut UNESCO adalah "kemampuan menggunakan teknologi informasi dan komunikasi (TIK) untuk menemukan, mengevaluasi, memanfaatkan, membuat dan mengkomunikasikan konten atau informasi dengan kecakapan kognitif, etika, sosial emosional dan aspek teknis atau teknologi”.

Martin dalam Koltay (2011) menyatakan bahwa

"Digital Literacy is the awareness, attitude and ability of individuals to appropriately use digital tools and facilities to identify, access, manage, integrate, evaluate, analyse and synthesize digital resources, construct new knowledge, create media expressions, and communicate with others, in the context of specific life situations, in order to enable constructive social action; and to reflect upon this process." (Martin, 2006: 19)

Martin menjelaskan bahwa Literasi Digital adalah kesadaran, sikap, dan kemampuan individu untuk menggunakan alat dan fasilitas digital secara tepat untuk mengidentifikasi, mengakses, mengelola, mengintegrasikan, mengevaluasi, menganalisis, dan menyintesis sumber daya digital, membangun pengetahuan baru, menciptakan ekspresi media, dan berkomunikasi dengan orang lain, dalam konteks situasi kehidupan tertentu, untuk memungkinkan tindakan sosial yang konstruktif; dan merenungkan rangkaian proses.

\section{METODOLOGI}

Penelitian ini menggunakan metode penelitian deskriptif kualitatif. Satori \& Komariah (2011: 23) mengungkapkan bahwa penelitian kualitatif dilakukan karena peneliti ingin mengeksplor fenomena-fenomena yang tidak dapat dikuantifikasikan yang bersifat deskriptif seperti proses suatu langkah kerja, formula suatu resep, pengertian-pengertian tentang suatu konsep yang beragam, karakteristik suatu barang dan jasa, gambar-gambar, gaya-gaya, tata cara suatu budaya, model fisik suatu artifak dan lain sebagainya.

Penelitian deskriptif kualitatif merupakan rangkaian aktivitas guna mendapatkan data yang bersifat apa adanya dalam kondisi tertentu yang hasilnya lebih menekankan makna dan bersifat induktif. Dalam penelitian ini, peneliti menggunakan metode penelitian deskriptif kualitatif karena penelitian ini mendalami fenomena perkembangan literasi digital sebagai salah satu tantangan baru dalam literasi media. 
Metode pengumpulan data ialah cara menggunakan instrumen-instrumen yang dipilih untuk dijadikan sebagai sumber data dalam melakukan penelitian. Metode pengumpulan data yang dilakukan ialah :

1. Observasi

Observasi merupakan teknik yang mendasar dalam penelitian. Observasi dilakukan dengan pengamatan yang jelas, rinci, lengkap, dan sadar tentang perilaku individu sebenarnya di dalam keadaan tertentu. Kemampuan dalam menentukan faktor-faktor awal mula perilaku dan kemampuan untuk menggambarkan secara akurat reaksi individu yang diamati dalam kondisi tertentu.

Observasi dalam penelitian kualitatif dilakukan terhadap situasi sebenarnya secara wajar, tanpa dipersiapkan atau dirubah untuk kebutuhan penelitian. Observasi dilakukan pada obyek penelitian sebagai sumber data dalam keadaan asli. Satori \& Komariah (2011: 148).

\section{Dokumentasi}

Menurut Satori \& Komariah (2011: 149), studi dokumentasi yaitu mengumpulkan dokumen dan datadata yang diperlukan dalam permasalahan penelitian lalu ditelaah secara intens sehingga dapat mendukung dan menambah kepercayaan dan pembuktian suatu kejadian.

Pendekatan analisis dengan menggunakan beberapa metode analisis yaitu analisis data interaktif yang terdiri dari pengumpulan data, analisis data, verifikasi data dan kesimpulan serta perumusan hasil. Milles and Huberman (2009:10-12) menyatakan bahwa analisis penelitian kualitatif terdiri dari tiga tahapan yaitu reduksi data (data reduction), penyajian data (data display), gambaran kesimpulan dan verifikasi (conclusion drawing and verification).

Tahapan dalam analisis data dapat dilihat pada gambar-gambar di bawah ini: 


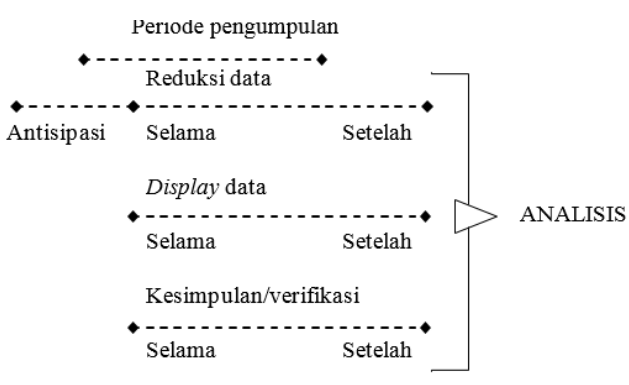

Gambar 1. Komponen dalam analisis data (flow model)

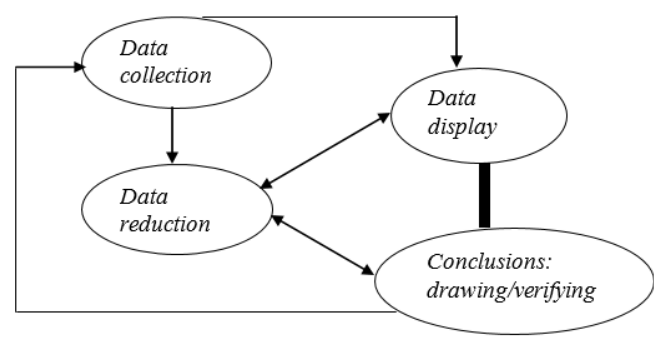

Gambar 2. Komponen dalam analisis data (interactive model)

Melakukan teknik verifikasi informasi dengan metode triangulasi yang merupakan usaha mengecek kebenaran data atau informasi yang diperoleh saat pengumpulan data, sehingga fenomena yang diteliti dapat dipahami dengan baik sehingga diperoleh kebenaran tingkat tinggi karena dilihat dari banyak sudut pandang. Triangulasi yang dilakukan ialah kombinasi triangulasi sumber dan triangulasi metode, diawali dari penemuan data dari sumber mana saja lalu dicross check pada sumber lain dengan metode yang lain juga sampai data lengkap dan validasi dari sumbersumber lain sehingga ada dasar untuk penarikan kesimpulan.

Instrumen untuk triangulasi data yang akan digunakan ialah lembar catatan data untuk membantu mengorganisir data,

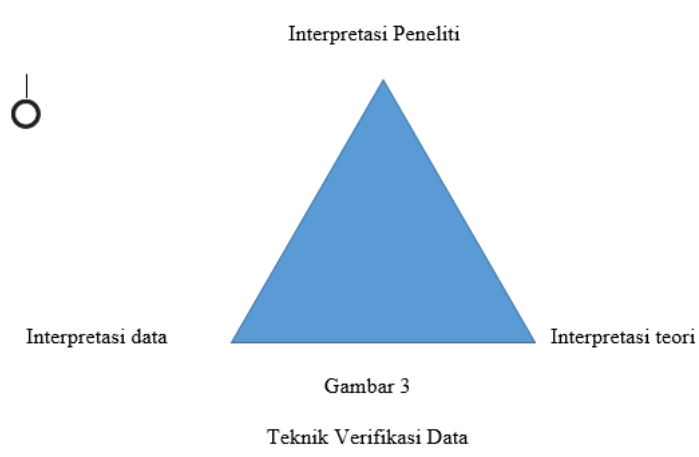

membuat risalah sementara juga untuk kebutuhan cross check data (yang sudah ada atau belum, yang layak analisis atau tidak, sudah dikonfirmasi dengan data lain atau belum).

\section{HASIL DAN PEMBAHASAN}

Menurut survey eMarketer, November 2014, Indonesia berada pada peringkat ke-6 sebagai negara dengan pengguna internet terbanyak. Tercatat 123 juta pengguna internet di awal tahun 2018, dan jumlah ini akan terus meningkat sehingga diprediksi akan naik ke peringkat 4 pada tahun 2018 akhir. Banyaknya pengguna smartphone dan juga internet dipengaruhi faktor-faktor sebagai berikut:

1. Semakin kompleksnya kebutuhan informasi. Adanya keinginan 
masyarakat untuk mengetahui apa yang sedang terjadi di belahan dunia yang lain, dan dengan menggunakan internet, hal ini menjadi semakin mudah.

2. Internet menjadi bagian dari sarana pendidikan dan pembelajaran. Proses belajar mengajar semakin terbantu dengan adanya perkembangan teknologi internet.

3. Internet dan penggunaan smartphone membuka jaringan bisnis yang lebih luas dan menjadikan bisnis lebih efektif.

4. Internet dan penggunaan smartphone merupakan alat komunikasi yang efektif, mampu menjangkau massa yang lebih luas dan cepat.

\section{Gambar V \\ Prediksi 10 negara dengan pengguna internet terbanyak, 2013-2018 (dalam juta jiwa)}

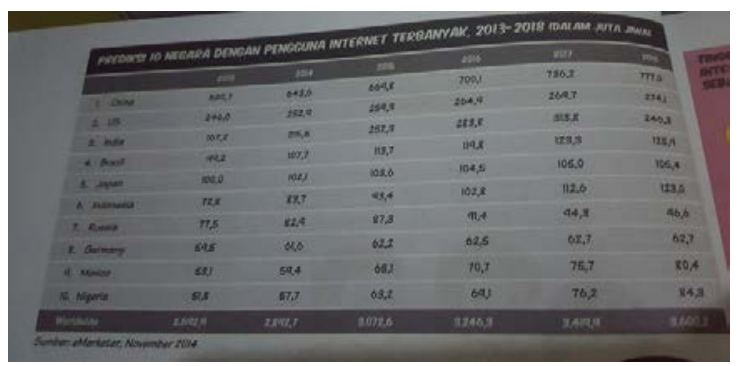

Sumber: eMarketer, November 2014

Livingstone (2004) dalam studinya menyatakan terdapat 4 komponen yang membentuk pendekatan dengan basis keterampilan dalam literasi media yaitu Pertama, akses, merupakan proses dinamis dan sosial, tindakan yang terus menerus sehingga dapat dilihat kualitas berkelanjutan dari layanan penyediaan akses dan konten media. Dengan adanya media baru, penyediaan akses di bidang pendidikan, partisipasi dan juga budaya dibutuhkan untuk lebih terhubung dengan konteks sosial masyarakat. Kedua, analisis. (Eco, 1979) dalam Livingstone (2004) menjelaskan hubungan yang berkelanjutan dan memuaskan dengan teks-teks simbolik terdapat pada kompetensi analitis, dimana pengguna harus kompeten dan memiliki motivasi akan tradisi dan nilai-nilai budaya yang relevan. Sejalan dengan itu (Bazalgette, 1999) dalam Livingstone (2004) menjelaskan skema analisis mulai dari agensi media, kategori media, teknologi media, bahasa media, khalayak media dan representasi media. Enam tahapan skema ini merupakan tahapan analisis awal yang efektif digunakan untuk media baru. Ketiga, evaluasi. Kemampuan dalam mengevaluasi konten memerlukan keterampilan yang mumpuni karena melibatkan evaluasi kritis mengenai pengetahuan umum dan juga konteks politik, ekonomi, sosial juga budaya dari konten yang didapatkan. Dan yang keempat, konten. Konten merupakan materi hasil produksi berdasarkan pengalaman pembuatnya. Pembuatan konten yang 
profesional menyampaikan ide, gagasan, aspirasi dan kreatifitas sebagai bentuk kontribusi dan partisipasi budaya di masyarakat. Dengan berkembangnya teknologi, membuat konten menjadi lebih mudah karena didukung pula dengan tersedianya platform yang mudah digunakan, kamera digital high definition sehingga gambar yang dihasilkan jauh lebih berkualitas, namun dengan segala kemudahan yang ada, konsekuensinya ialah pembuat konten harus mampu membangun ikatan antara pembuat dan penerima konten dimana harus ada konteks kebermanfaatan untuk pembelajaran, manifestasi budaya dan kontribusi masyarakat.

Jumlah informasi yang tersedia dalam berbagai bentuk konten di banyak media membuat masyarakat kita kewalahan dalam menerima informasi. Segala sesuatu yang digital sebetulnya hanya merupakan alat, hasil peradaban, teknologi yang dibuat oleh manusia. Maka meski bagaimanapun gempuran konten digital yang terjadi saat ini, kita masih bisa melakukan tindakan yang bermakna, salah satunya dengan menjadi cerdas, kreatif dan produktif dalam literasi media. Salah satunya ketika menggunakan media sosial, maka diperlukan etika berinternet yang menjunjung asas kehati-hatian serta selalu beritikad baik dalam kegiatannya, seperti:

1. Menulis dengan ejaan yang baik dan benar. Memperhatikan penggunaan huruf besar dan kecil sesuai dengan aturan penulisan dalam Bahasa Indonesia. Contohnya penggunan huruf kapital akan diasosiasikan dengan kemarahan ketika itu dipublikasikan di salah satu platform media sosial, sehingga akan menimbulkan asumsi-asumsi negatif terhadap si pembuat konten.

2. Memastikan setiap sumber informasi yang diterima. Melakukan pengecekan kembali dan mengkonfirmasi bahwa berita yang didapatkan bukan berita hoax atau spam. Kredibilitas kita sebagai individu akan menjadi dipertanyakan apabila kita sharing info tanpa saring terlebih dahulu.

3. Tidak mengumbar pesan pribadi ke ranah publik. Meskipun menggunakan sosial media, sebaiknya informasi-informasi yang berada pada ranah pribadi, bersifat privasi disampaikan lewat private message.

4. Apabila kita mengupload sebuah post yang sumbernya berasal dari tulisan orang lain, selalu cantumkan sumber informasi aslinya. Karena apabila tidak, maka kita tidak menghargai orang lain dan melakukan tindakan plagiarisme.

5. Menghindari perdebatan akibat perbedaan pendapat yang akan 
berujung pada perselisihan. Contoh yang banyak terjadi ialah akibat dari penggunaan kalimat yang menyinggung SARA atau kalimatkalimat yang tidak sopan.

6. Menggunakan teknologi, media sosial dengan kreatif yang mampu menciptakan kebaruan yang bermanfaat dan memiliki nilai tambah. Contohnya seperti Penyanyi Raisa yang memulai karir menyanyinya dengan mengunggah videonya di Youtube, atau Walikota Bandung, Ridwan Kamil yang menyosialisasikan program-program dan bekomunikasi dengan warganya melalui twitter.

(Jolls dan Thoman, 2008) dalam Koltay, 2011 menjelaskan bahwa saat ini terjadi tingkat konsumsi media yang tinggi yang menyebabkan masyarakat mulai jenuh dengan media. Karena dalam kehidupannya, masyarakat menjadi sangat terpengaruh oleh persepsi, keyakinan dan sikap yang ditampilkan media, sehingga muncul kebutuhan informasi yang lebih efektif yang ditunjang dengan komunikasi yang lebih tereksplorasi. Literasi media melibatkan pemahaman, cara menafsirkan, tingkat analisis kritis dan penyusunan kesimpulan dari teks untuk menjadi subjek penelitian pada berbagai bidang mulai dari komunikasi, sastra, budaya, ekonomi, sejarah, pengetahuan umum dan tentunya kajian media.

Livingstone (2004) dalam studinya menyatakan bahwa dalam perkembangan media baru, termasuk diantaranya internet dan media sosial, dibutuhkan upaya untuk menganalisis teks multimedia, interaksi, keragaman budaya, hingga estetika visual. Dapat dilihat dari 7 kategori media sosial dengan karakteristik yang spesifik, yaitu:

1. Jejaring sosial, memungkinkan pengguna untuk membuat dan mengelola halaman sendri, berbagi konten dan membangun hubungan pertemanan. Contoh: Facebook.

2. Blog, lebih dikenal sebagai jurnal online, dimana pengguna bisa mencatat berbagai hal yang bersifat informasi, ide/gagasan, buah pemikiran, hasil pandangan atau bahkan pengalaman pribadi. Contoh: Kompasiana

3. Wikis, memungkinkan pengguna untuk melakukan penambahan, pengurangan, edit data/informasi dan kemudian menyimpannya kembali. Contoh: Wikipedia.

4. Forum, media komunitas online, berupa tempat diskusi secara online, biasanya bagi orang-orang yang memiliki hobi/minat/bakat yang sama untuk sharing atau bahkan turut menciptakan tren/wacana publik. Contoh: Kaskus. 
5. Sharing konten, memberikan kemungkinan pengguna untuk berbagi dan mengelola berbagai jenis konten seperti foto dan video. Contoh: Youtube

6. Microblogging, perpaduan antara jejaring sosial dengan blog dalam skala konten yang lebih kecil yang mengutamakan kecepatan saat berbagi konten. Contoh: Twitter.

7. Media sosial komersil, digunakan untuk menjual konten seperti dalam bentuk musik atau video. Contoh: Itunes.(Nasrullah, 2015)

Dari ketujuh kategori media sosial diatas, konten yang dianalisis berfokus pada pesan yang perlu dipahami secara sinergis dengan teknologi. Jendela informasi yang semakin terbuka secara otomatis juga memberikan saluran yang lebih luas untuk masyarakat dalam membuat konten dan menerima informasi. Dalam literasi media, tahapan mulai dari identifikasi, perancangan sistem untuk membantu membuat pemahaman sehingga dapat menghasilkan makna dilihat dari gambar/kata-kata/suara yang terdapat dalam konten.

(Bawden, 2006) dalam Koltay, 2011 mendeskripsikan literasi digital sebagai berikut:

"Digital literacy touches on and includes many things that it does not claim to own. It encompasses the presentation of information, without subsuming creative writing and visualization. It encompasses the evaluation of information, without claiming systematic reviewing and metaanalysis as its own. It includes organization of information but lays no claim to the construction and operation of terminologies, taxonomies and thesauri. (2008: 26)"

Literasi digital pada umumnya terbatas pada penggunaan media yang ditunjang dengan teknologi informasi dan komunikasi. Berdasarkan deskrispi diatas, Bawden menjelaskan bahwa literasi digital mencakup banyak hal mulai dari pengorganisasian, penyajian informasi dan visualisasi hingga evaluasi informasi. Literasi digital meliputi berbagai literasi sehingga menjadi lebih kompleks. Sama halnya dengan literasi media, literasi digital juga memerlukan kemampuan menganalisis dan evaluasi secara kritis sehingga memperoleh pemahaman yang berkualitas. Dalam literasi digital, pesan di media dikonstruksi sedemikian rupa sehingga mampu berfungsi maksimal dalam situasi komunikasi yang lebih kompleks sekalipun. Literasi digital memiliki skala yang lebih luas dan biasanya membahas isu penting. Pendidikan literasi digital dapat dimulai dari mengasah keterampilan dalam membaca konten, dengan rajin membaca konten, maka penggunaan literasi digital 
untuk pemahaman konten akan lebih kritis. Banyaknya konten di internet misalnya, selain memberikan banyak kemudahan namun juga berdampak negatif bagi para penggunanya. Dengan tingginya jumlah pengguna internet di Indonesia, maka dibutuhkan tata cara atau etika yang menjadi pedoman bagi para pengguna dalam menggunakan internet. Indonesia sebagai negara yang menjungjung tinggi agama dan berbudaya memiliki normanorma seperti:

1. Sopan santun. Dalam berinternet gunakanlah bahasa yang sopan supaya tidak ada orang yang tersinggung. Mengupload foto atau video yang sopan, tidak mengandung unsur SARA atau pornografi dan menghormati privasi orang lain.

2. Ramah tamah. Internet dapat dimanfaatkan untuk memperpanjang silaturahmi, menambah saudara. Istilah mendekatkan yang jauh dan menjauhkan yang dekat memang banyak terjadi, namun sebagai pengguna yang cerdas alangkah lebih baik apabila internet digunakan dengan lebih bijak.

3. Gotong royong. Norma gotong royong telah menjadi ciri khas bangsa Indonesia. Internet dapat dimanfaatkan untuk membantu orang lain, misalnya membuat dan menyebarkan tulisan untuk membantu orang yang membutuhkan. Atau apabila kita memiliki keterampilan di bidang software, kita bisa membuat aplikasi yang dapat mempermudah aktivitas pengguna.

4. Toleransi tinggi. Dengan beraneka ragam suku, agama dan ras yang ada di negara ini, maka kita perlu memiliki toleransi yang tinggi. Menghargai setiap perbedaan dan keberagaman setiap individu yang ada di dunia maya, tidak mudah terpancing dengan isu-isu SARA yang belum jelas kebenarannya.

5. Tabayyun, artinya mencari kejelasan tentang sesuatu hingga jelas benar keadaannya. Dibutuhkan kehatihatian akan semua informasi yang diterima, apabila diperlukan carilah referensi sumber berita yang dapat dipercaya.

Selain norma-norma sebagai pedoma etika berinternet, Indonesia sebagai negara hukum juga memiliki aturan hukum dalam berinternet, diantaranya:

a. Undang-undang Nomor 11 Tahun 2008 tentang informasi dan Transaksi Elektronik yang megatur tentang informasi dan transaksi elektronik dan pengaturan mengenai perbuatan yang dilarang.

b. Undang-undang Nomor 44 Tahun 2008 tentang Pornografi yang didalamnya termasuk mengatur 
perbuatan apa saja yang masuk dalam tindakan pornografi, termasuk tulisan, foto atau video yang diupload atau disebarkan di internet.

c. Surat edaran Kapolri Nomor SE/6/X/2005 tentang Penanganan Ujaran Kebencian (Hate Speech). Barangsiapa yang melakukan ujaran kebencian seperti penghinaan, pencemaran nama baik, penistaan, perbuatan tidak menyenangkan, provokasi, menghasut dan menyebarkan berita bohong/hoax baik sengaja maupun tidak disengaja yang berdampak pada tindakan diskriminasi, kekerasan, penghilangan nyawa atau konflik sosial maka akan terkena ancaman tindak pidana. Surat edaran ini juga berlaku pada tindakan yang dilakukan di platform internet atau media sosial.

\section{SIMPULAN}

Komunikasi saat ini mengimplikasikan tidak hanya pada bagaimana sebuah teks dibuat, melainkan melibatkan proses pemilihan, pengaturan, filterisasi dan bagaimana cara merangkai kembali informasi yang sudah diterima. Fenomena teknologi digital semakin menguatkan bagian dasar dari literasi digital yaitu bagaimana mendapatkan informasi dan menghubungkannya dengan konteks yang akan dibuat.

Warga negara yang mengonsumsi media, semakin perlu memahami bahwa literasi, baik media maupun digital itu penting. Hal ini dikarenakan informasi di media menjadi semakin bervariasi, teknologi digital semakin berkembang dan juga melibatkan partisipasi dari masyarakat yang semakin luas. Perlu adanya kesadaran literasi media dan literasi digital mulai dari tingkat sekolah dasar hingga pendidikan tinggi. Literasi digital turut merangsang perkembangan pengetahuan dan meningkatkan keterampilan seseorang dalam menafsirkan teks media dan menggunakan teknologi, serta kemampuan berinteraksi baik antara pengguna dan teknologi maupun antara pengguna dan penerima konten.

Sebagai warga negara yang bertanggung jawab, maka diperlukan pemahaman yang lebih luas tentang akses, analisis, evaluasi kritis dan pembuatan konten yang lebih mengarah pada perkembangan media baru. Dibutuhkan pengguna yang secara sadar melakuan penyeleksian, mengenal dan memberikan respon dan juga berpartisipasi sebagai bagian dari warga negara yang cerdas, kreatif dan juga produktif dalam bermedia. 


\section{DAFTAR PUSTAKA}

eMarketer. 2014. Diakses pada 6 Juni 2018. https://www.emarketer.com/corporate /in-the-news/nov-2014.

Koltay, T., (2011). The media and the literacies: media lietracy, information literacy, digital literacy. Journal Media, Culture \& Society. 33(2). 211221. Diakses pada 8 Juni 2018. DOI: $10.1177 / 0163443710393382$.

Livingstone,. S., (2004). Media literacy and the challenge of new information and communication technologies. Communication

Review Journal, 1(7). 3-14. Diakses pada 6 Juni 2018.

Potter, James. W. (2004). Theory of Media Literacy: a Cognitive Approach.

California: Sage Publications.

Satori, D., Komariah., A., (2011). Metodologi Penelitian Kualitatif, Bandung. Alfabeta.

Matthew B. Miles \& A. Michael Huberman, Analisis Data Kualitatif, Jakarta: Universitas Indonesia. UIPress, 2009.

Nasrullah,. R., (2015). Media sosial, perspektif komunikasi, budaya dan sosioteknologi. Bandung. Simbiosa Rekatama Media

Littlejohn, W. Stephen., Foss. K.A., (2009). Encyclopedia of Communication Theory. United States of America, Sage Publications, Inc. 